Article

\title{
Bangladeshi Migrants of Italy and Their Precarity
}

\author{
Nilanjana Roy ${ }^{1}$ and Amy Verdun ${ }^{2,3, *(1)}$ \\ 1 Department of Economics, University of Victoria, Victoria, BC V8W 2Y2, Canada; nroy@uvic.ca \\ 2 Department of Political Science, University of Victoria, Victoria, BC V8W 2Y2, Canada \\ 3 Institute of Political Science, Leiden University, NL 2333AK Leiden, The Netherlands \\ * Correspondence: averdun@uvic.ca
}

Received: 20 February 2019; Accepted: 11 April 2019; Published: 19 April 2019

\begin{abstract}
Over the past years much attention has been placed on the ordeal of migrants as they leave their home countries and seek refuge or better lives in others. Given the sudden surge of Bangladeshi migration to Italy in recent years, this article focuses on Bangladeshi migrants in Italy and examines the precarity that they face or have faced. Our analysis is based on observations gleaned from the existing literature and our own field study of 18 Bangladeshi migrants in two adjacent regions in Italy. We look at the precarity faced by Bangladeshi migrants (1) pre-migration in Bangladesh, (2) during migration from Bangladesh as they passed through different countries, and (3) in their current host country, Italy. Precarity can have different but often overlapping meanings, for example, "labor precarity", "life precarity", and "place/legal precarity", among others. We have used these different lenses of precarity to examine the experience of Bangladeshi migrants of Italy. The existing literature on Bangladeshi migrants does not use a precarity lens explicitly, nor does it consider the experience of the migrants in all three of the above stages of their migration together. We conclude that generally these Bangladeshi migrants face precarity in its various forms, in all stages of their journey, and in many spheres of life in their current host country. Recognizing the precarious nature of the existence of many of the Bangladeshi migrants is very important in any discussion of migrant issues that their host country, Italy, is facing.
\end{abstract}

Keywords: Bangladeshi migrants; Italy; precarity; well-being

\section{Introduction}

More and more people are leaving their home countries and seeking refuge or better lives in other countries. As they do so, many are trying to escape a precarious existence, but also face precarity in their destination countries and/or the country or countries that they travel through to reach them.

In recent years, many images and media reports have captured the attention of the world with respect to vulnerable people facing dangerous circumstances both during their journeys and upon arrival in their new countries. ${ }^{1}$ Thus, there is a strong need for further research to learn about the experiences of the border crossers prior to their departure, posterior to their arrival at their destination, and during their journeys through other countries on the way. Knowing their experiences will add to others' understanding of the precarity that this group faces and may even help shift negative public opinion about migrants.

This article aims to contribute to that research on the experiences of vulnerable border crossers and considers the case of a particular group of border crossers, namely Bangladeshi migrants in Italy.

1 For instance, the photograph of the three-year-old Syrian boy identified as Alan Kurdi, who was found dead on a Turkish beach in September 2015, made global headlines. 
We seek to examine how precarious the life and work of Bangladeshi migrants was before and after migration to Italy. We describe how the precarity of this group of people relates to: (1) the vulnerability and insecurity in their existence in their home country of Bangladesh, (2) the precariousness ${ }^{2}$ in their actual journey(s) or crossing(s), and (3) the precarity that they face in their host country, Italy. We operationalize the concept of precarity by examining labor, life, and place/legal precarities. While our analysis is primarily based on observations collected from the existing literature on Bangladeshis, we also present some insights from our own field study of Bangladeshi migrants in the two Italian regions of Emilia-Romagna and Tuscany, undertaken in June 2018. These further insights into the various aspects of labor, life, and place/legal precarities faced by these migrants were obtained by interviewing 18 individuals. ${ }^{3}$ Even though there are numerous other Bangladeshis in Italy living in much more precarious circumstances, the story of even our relatively better-off merchants provides evidence of precarity. Therefore, the situations of the Bangladeshi migrants who are unemployed or underemployed as street vendors or hawkers are many times more precarious, and indeed they face many other challenges that make life extremely difficult for them.

The migration situation in Europe has been brought to the public attention with the surge of migrants in 2015. This quickly received the name of "refugee crisis" (Lavenex 2018, p. 1196), when more than one million migrants and refugees crossed into Europe that year ${ }^{4}$. This was the greatest migration flow since the Second World War; 3-4 times more individuals migrated that year as compared to the year before (IOM 2015). By 2016, two million migrants had entered Europe (European Parliament 2017). Italy has seen some of the largest numbers of migrants. Currently, more than $10 \%$ of Italians are foreign-born (Eurostat 2019). Bangladeshi migrants have in recent years increased in number. They recently became the eighth largest non-EU group of migrants in Italy (Italian Ministry of Labour and Social Policies 2016). By the middle of 2017, statistics of the Ministry of the Interior and the International Organization for Migration found that Bangladeshis were the second largest group arriving in Italy (Cupolo 2017; Ghiglione 2017). The sudden surge in Bangladeshi migration to Italy has emerged due to a multitude of reasons. While we do not delve into these in this article, this increased presence of Bangladeshi migrants in Italy contributes to the importance of studying their situation.

The remainder of this article is structured as follows. The next section provides the various possible meanings of the term "precarity" that exist in the literature. In Section 3 we provide a discussion of the various ways that Bangladeshi migrants are experiencing precarity. Section 4 presents some findings related to precarity from our field research. The final section concludes by indicating the usefulness of the concept of precarity for an understanding of the experiences of Bangladeshi migrants who are in Italy.

\section{Precarity-A Definition and Literature Review}

The term "precarity" has become important in recent years, as evidenced by the data presented by Paret and Gleeson (2016), who showed that the frequency of the term "precarity" mentioned in Google searches went from 0 in the period 2004-2009 to 877 in 2015. The word "precarity" and its associated

2 For the difference between "precarity" and "precariousness" see Neilson and Rossiter (2005). Here we use the words interchangeably.

3 Our research was granted ethics approval by the University of Victoria and was assigned Protocol Number 18-182.

4 We use the term 'migrants' throughout this article, in line with the usage of the United Nations (UN), that, although it recognizes that there is no generally agreed to definition, defines the term as follows "... an international migrant is someone who changes his or her country of usual residence, irrespective of the reason for migration or legal status. Generally, a distinction is made between short-term or temporary migration, covering movements with a duration between three and 12 months, and long-term or permanent migration, referring to a change of country of residence for a duration of one year or more." The UN follows the 1951 Convention and regional refugee instruments, when it defines refugees as follows: "Refugees are persons who are outside their country of origin for reasons of feared persecution, conflict, generalized violence, or other circumstances that have seriously disturbed public order and, as a result, require international protection." (United Nations 2018). Although there are established usages of both 'migrants' and 'refugees' or 'asylum seekers' as mutually exclusive, we will not differentiate among those in this article and simply use the broader category of 'migrants' as defined above. 
forms such as "precarious" (adjective) and "precariousness" (noun) are derived from the Latin word precarious, which means something obtained through prayer or petition (Biglia and Martí 2014). In the romance languages this meaning continued but "[ ... ] more in general they were used in reference to circumstances that could be characterized as uncertain, insecure, and unstable" (Biglia and Martí 2014, p. 1488). However, the word has taken on new, more specific meanings since the late 1970s. We discuss below some of the ways various authors have defined precarity.

Biglia and Martí (2014) provide two different meanings, acknowledging the possible overlap between them based on the vast literature on precarity, and term them "labor precarity" and "life precarity". According to them, labor precarity "refers to a situation in which subjects are faced with flexible working conditions. These circumstances include temporary employment, nonstandard work contracts or schedules, and/or employment without social security or benefits" (Biglia and Martí 2014, p. 1489). By contrast, life precarity "refers to a situation in which persons do not have stable life conditions. [ ....] This implies a lack of life security and a feeling of permanently living in a "state of flux" - an unstable environment with no options for making plans for the future, even the very near one" (Biglia and Martí 2014, p. 17). While the former definition has a narrow focus on employment, the latter is broader and can be tied to feelings of vulnerability that could arise not just due to labor market situations, but from various life experiences and prospects.

Millar (2017) identifies three often-referenced works on precarity, (Bourdieu 1998; Standing 2011; Butler 2004) and examines three distinct meanings of the term: precarity as a "labor condition", "a class identity", and "an ontological experience of human existence [ ... ]" (Millar 2017, p. 2). Millar provides a very useful discussion about the evolution of the meaning of the term "precarity" in recent times. We provide a short summary of that here to lay out the meanings that we would use in Sections 3 and 4 to examine the various dimensions of precarity with respect to Bangladeshi migrants in Italy.

Bourdieu et al. (1963) introduced the concept of "precarity" while studying unemployed and underemployed workers in Algeria in the 1960s, but the term really started gaining attention in academic and policy circles in the late 1970s through the works of French sociologists and policymakers who associated precarity more broadly with poverty and not employment conditions (Barbier 2002; De Peretti 2005; Millar 2017). Bourdieu (1998), writing at a time of rising labor insecurity in Europe, reintroduced the meaning of precarity from his previous work and defined it once again in terms of employment insecurity. While many others have defined precarity in this narrow sense ${ }^{5}$, Standing (2011), another prominent voice in the literature on precarity still sticking to the domain of labor conditions, differed from Bourdieu et al. 1963, Bourdieu 1998 by introducing the term "precariat", thus defining precarity as a class category.

Butler's conceptualization of precarity is yet more distinct from that of Bourdieu and Standing, and to her precariousness ${ }^{6}$ relates to "a common vulnerability, one that emerges with life itself" (Butler 2004, p. 31). While the vulnerability exists for everyone, Butler recognizes that this affects people unequally depending on individual attributes such as class, age, and nationality, among other factors. To her, precariousness is not simply a fact of life but a fact of our sociality. We are interdependent and that interdependence brings vulnerability. This vulnerability is related to the possible loss of those who we are close to due to violence and at the same time it is related to the possibility of us experiencing violence because of our dependence on others. Hence, for Butler, precariousness is relational (Millar 2017). Butler's way of thinking has influenced others (e.g., Banki 2013; Hundle 2012; Tsing 2015) to use the term "precariousness" as synonymous to vulnerability or instability.

In her later writings on precarity, Butler (2009a, 2009b) argues that the state is obliged to protect populations from suffering; to ensure that people have social and economic networks of support, and that they should not be subject to poverty, disease, displacement, and violence. In this sense

5 See (Millar 2017) for references to such work.

6 Butler draws a distinction between the concepts of precariousness and precarity. For more details on that, please see (Millar 2017) and the references therein. For the purpose of this article, we use the terms interchangeably. 
she defines precarity as follows: "Precarity also characterizes that politically induced condition of maximized vulnerability and exposure for populations exposed to arbitrary state violence and to other forms of aggression that are not enacted by states and against which states do not offer adequate protection" (Butler 2009b, p. ii).

Others besides Millar (2017) have also discussed the different meanings of precarity based on the literature (for example, see Buchanan 2018). Buchanan, drawing on Standing (2011) defines the term as "[a\} state of being defined by insecurity and vulnerability. [ . . ] it tends to be used to refer to people who are unemployed, underemployed, or insecurely employed". Again, this is precarity in the labor condition sense. Building on the work of Butler (2009a) he points to precarity as "[ ... ] a politically induced state. It refers to a situation in which a person or group of persons have been pushed into a state of precariousness by circumstances beyond their control, e.g., refugees. Precarity in this sense is a condition of maximum vulnerability for which there is no obvious source of relief" (Buchanan 2018, p. 1). Here precarity is seen as more than a labor condition and can be considered to be a life condition.

Another related meaning of precarity has been discussed by Neilson and Rossiter (2008) who provide an overview of the burgeoning literature on the topic between 2003 and 2008. There the term is connected to a decline in the capitalist mode of production, generally associated with the term "Fordism" - itself a term that assumed stable working relations and a predictable cradle-to-grave working conditions - in the face of what is often referred to as "neoliberal" reforms (Neilson and Rossiter 2008, p. 54).

Applying the concept of "precarity" to migrants, especially in developed economies, Nicholas Henry, drawing on the works of Standing (2011) and Butler (2004) also connects the term to "changes in forms of production and employment associated with post-Fordist or neo-liberal globalization" (Henry 2018, p. 165). Applied to the migrant worker Henry sees precarity related to the possibility of unemployment, or a "power-over" situation that can be exploited by an employer. There is also a second dimension namely that:

[... ] for migrant workers and asylum seekers, the precarity of their position is defined by the deliberate policy decisions and state actions that make up the migration border regime. Each dimension of vulnerability that produces migrant precarity is produced by a real and present threat underpinned by state violence or neglect. The vulnerability of migrants with irregular status is defined by the threat of arrest, detention and deportation, the arbitrary enforcement of the carceral immigration regime [... ] The vulnerability of migrant workers is added to by the threat of total poverty that unemployment represents in conditions where the worker lacks access to social protection and welfare systems. (Henry 2018, p. 167)

In other words, their precarious position is further heightened by the lack of state protection and the fact that the state can impose threats and violations of their safety in various ways.

Finally, Susan Banki introduces the concept "precarity of place" ("vulnerability to removal from a country" (Banki 2013, p. 452)) which concentrates on "denizens": people who are not citizens but have the legal right to be resident or those who are frequently residing in a given space. Building on Banki's concept one could argue that these individuals are non-citizens, sometimes not even having the full necessary legal status in the host country, who face a number of risks: being deported, change of labor laws or immigration laws that could be unfavorable to non-citizens, or not necessarily having full rights to cross borders leading to the risk of not be able to re-enter the host country if they cross the border. This precarity of place is closely connected to precariousness around not having the correct legal documentation and status to reside lawfully in the country and/or to travel freely back to the mother country and have the right to reenter after a short time away.

In terms of our analytical framework, for the purpose of this article and drawing on the above literature, we examine precariousness of the Bangladeshi migrants in Italy using, as appropriate, three notions of precarity: as a labor condition, a life condition, and as a legal condition. Following the 
notion of precarity as a labor condition, we will be providing evidence of employment insecurities in all three stages of a migrant's journey. Our discussion will also highlight experiences of the migrants that are more generally associated with human vulnerabilities and hence fall under the definition of precarity as a life condition (for example, poverty, natural disasters, dangerous crossings, among others). We also discuss the "precarity of place" faced by the migrants in terms of vulnerabilities and insecurities resulting from statelessness in the absence of appropriate legal status. While there are relations between these various notions of precarities faced by the Bangladeshi migrants, we find it helpful to use the various notions of precarity from the literature to show that the migrants are facing precarity not just in one form but in multiple forms.

\section{Bangladeshi Migrants in Italy and Their Precarity}

In this section we examine precarity, as understood in its different meanings, in the lives of the Bangladeshi migrants in Italy. While the migrants face precarity in many dimensions of their present lives in Italy, we seek also to shed light on the past experiences of precarity that these individuals may have faced in Bangladesh prior to their emigration from there and/or those that they may have experienced in the journey between Bangladesh and Italy. By looking at precarity from all these angles we aim to provide a more complete picture of the precariousness in the lives of this group of migrants. The existing literature on Bangladeshi migrants does not use a precarity lens explicitly nor does it consider the experience of the migrants in all stages of their migration together. By detailing the various types of precarity faced by many of these migrants in different stages of their journey, we show the overlapping as well as accumulating precarity faced by them. Such knowledge can help one understand the tremendous difficulties that many of these migrants face in life.

\subsection{Precarious Life in Bangladesh}

While Bangladesh has made impressive progress in reducing its poverty rate, it is still a poor country. In 1991, 44.2\% of the population lived below the poverty line; by 2016-2017 this figure had been brought down to $13.8 \%$. This percentage of the Bangladeshi population nevertheless translates to 22 million people (World Bank 2018). To put this number into perspective, it would equal roughly $60 \%$ of the Canadian population in the same year. Thus, for a large number of Bangladeshis the situation is still quite dire.

Furthermore, Bangladesh, as many other developing countries, is facing the challenges of continued urbanization, with approximately 35\% of its total population living in urban areas in 2016 (World Development Indicators 2018). On the educational front, the picture is not very positive either. While the percentage of the labor force that had no education decreased from $48.1 \%$ in $1999-2000$ to $40.1 \%$ in 2010, the latter figure is still quite high (The Asian Development Bank and the International Labor Organization 2016). Therefore, while there have been improvements in education, especially in female education over the years, Bangladeshis continue to suffer from lack of education. While low education has labor market implications for the types of jobs many Bangladeshi can hold, this situation in itself creates vulnerability and insecurity that result from people being illiterate and being at the mercy of others (e.g., they may not understand what they are signing and can be taken advantage of by unscrupulous money lenders).

Around $40-50 \%$ of the labor force is employed in the agricultural sector, and this percentage remained relatively stable during the 1999-2013 period (The Asian Development Bank and the International Labor Organization 2016). This heavy dependence of a large proportion of the labor force on agriculture creates instability and vulnerability for the population since agriculture is weather-dependent. Bangladesh, being a low-lying nation in the world's biggest delta (created by three rivers as they empty into the Bay of Bengal), is prone to storms, cyclones, flooding, and soil erosion. Climate change is further risking the livelihood of Bangladeshis. As Donato et al. (2016, p. 203) discuss, "sea-level rise, land erosion, and growth in the intensity of weather patterns in this low-lying nation have led to non-sustainable land loss. Its many cyclones have led to thousands of deaths, widespread 
infrastructural damage, and have left millions homeless". The livelihood and survival of Bangladeshis are constantly challenged as the scale and frequency of extreme climate events has been steadily increasing in recent times. For example, the coastal villages of Bangladesh were hard hit by cyclone Sidr, a category 5 storm in 2007, and then again by cyclone Aila in 2009, which "[ . . ] caused widespread deaths, large-scale destruction of livelihoods and property forcing villagers to migrate. As repeated exposure to such disasters depletes the asset base of households, it makes future recovery very hard" (Kartiki 2011, p. 25). Many predict that the situation will only worsen as an effect of climate change (IPCC 2014; Khan 2012; Stojanov et al. 2017, among others).

While the environmental changes affect the coastal communities disproportionately, vulnerability related to livelihood can be found elsewhere and more generally as well. Whereas the total unemployment rate was around $4 \%$ in 2016, the unemployment rate among youths was $11.1 \%$, and that among those with advanced education was 16.8\% (World Development Indicators 2018). Other sources (e.g., Quayam 2017a) report even higher estimates. Also, it has been pointed out that the relatively low total unemployment rate:

[... ] is in part because people simply cannot afford to remain unemployed and try to eke out a living from whatever work they can get. As a result, a large proportion of the employed are engaged in work that can be called "vulnerable," such as self-employed, own account, unpaid family helper, and day labor. No universally accepted definition of vulnerability exists in this context, but the sense of vulnerability conveyed is from perspectives such as job stability and the income earned. (The Asian Development Bank and the International Labor Organization 2016, p. 3)

The employment situation in Bangladesh is further made worse by high levels of corruption, where connections and bribes are needed in order to get access to government jobs and admissions into elite schools and universities; the latter are important for access to jobs in private companies (Quayam 2017a). Another point made by Quayam (2017a) related to labor conditions is that unskilled workers, who mostly are migrants from the villages, typically work on a temporary contract basis in the cities in agriculture, construction, and transportation, and hence have very little to no employment stability.

In addition, the bitter rivalry between the ruling Awami League Party with the opposition Bangladesh Nationalist Party and Jamaat-e-Islami Party has led to lawlessness ${ }^{7}$ and political violence and death, adding to the instability and vulnerability in the lives of the people of Bangladesh. Even the once-booming garment industry is cooling down amidst concerns of working conditions, labor rights, and political violence (Mallet 2015).

While all the above factors may to a certain extent be contributing to the decisions of Bangladeshis to migrate, our point here is not primarily to identify migration drivers but to highlight the precarity that Bangladeshis face in their home country. These precarities are related to both labor and life precarity discussed in Section 2.

\subsection{Precarious Journey between Bangladesh and Italy}

Bangladesh has had a long history of migration, reaching back to the colonial times when it was under British rule and still part of India. The colonial links resulted in a few Bengali sailors with the British Merchant Navy settling in London in the 1920s, which in turn resulted in subsequent concentration of Bangladeshis in the United Kingdom as many more migrated via labor recruitment schemes in the 1950s and the 1960s as well as via family reunification in the 1970s and 1980s (Adams 1987; Knights 1996; Tinker 1977). However, these migration flows were minor compared to the later period.

Data presented by Riahan et al. (2009) based on the Bangladeshi Bureau of Manpower, Employment and Training (BMET) database show that the Bangladeshi migrant flow really started picking up from

7 Personal persecution was cited as a reason for migration by $30 \%$ of adult Bangladeshi migrants and $28 \%$ of Bangladeshi children interviewed by the International Organization for Migration (IOM 2017). 
the 1980s. They identify three phases of migration. The first phase was in the 1978-1989 period where Bangladeshi workers mainly went to Middle Eastern countries, especially to the six member countries of the Gulf Cooperation Council (GCC) ${ }^{8}$, in response to the labor demand arising from the 1973 oil boom. The second phase was the 1990-2000 period when the migration outflow quadrupled due to access to markets in Malaysia and Singapore. The third phrase was over the period 2001-2008 (the end period was determined by the data availability of Riahan et al. 2009) when Bangladeshis had access to other markets in Eastern Europe, Italy, and South Korea, among others. More recent data from the BMET (Government of Bangladesh 2018) show that while post-2008 the outflow of workers has fluctuated, it still never went below the 2006 level and in fact reached a new all-time high in 2017. When considering the BMET data it is important to keep in mind that these statistics do not include the total migration flow of Bangladeshis, as many go abroad illegally. ${ }^{9}$ Moreover, these statistics do not capture the total immigration of Bangladeshis into a particular destination country, as Bangladeshis often go through a number of countries before reaching their destination. For example, BMET data show that only 3 and 1 worker(s) went from Bangladesh to Italy in 2016 and 2017 respectively, while IOM (2017) estimated that 8,131 Bangladeshi migrants arrived by sea in 2016 alone.

While Bangladeshi migration to the GCC countries continues to remain strong, work opportunities are precarious. At the most extreme end of the spectrum, many Bangladeshi workers perish in the Middle East, with more than 8000 bodies being returned to Bangladesh between 2004 and 2009 (Quayam 2017a). Also, these workers are on short-term contracts with many restrictions on their stay in those countries. These issues are all indicators of the precarious existence of the Bangladeshi migrant workers in the Middle East, and are in line with the various dimensions of precarity as set out in Section 2.

Del Franco (2010), based on her survey of 27 households in Bangladesh and detailed interviews with some of the migrants and their family members, found that even those who were working in the Middle East wished to migrate to Italy, especially when one or more family members had settled in Italy and could help others get there. The reasons include hopes of higher earnings (recognizing that the initial years may involve hardships), better treatment in society, equality, and political stability, as well as a better functioning judicial system. In other words, they wish to escape their precarity, related to labor as well as life, in the Middle East. Morad and Gombač (2018) also found that many Bangladeshi migrants to Italy had first gone to the Middle East on a tourist visa and then to North Africa before moving on to Italy. Quayam (2017b) says of Bangladeshi workers in the GCC that "brutal working conditions combined with an economic slowdown and restrictive government policies toward migrant workers in the GCC are leading some to reroute their Dubai Dream to Europe" and in particular to Italy via Libya.

In recent times, Bangladeshi migrants have gone to Italy in three ways: irregular migration, the quota system, and family reunification (Mannan and Farhana 2014; Rahman and Kabir 2012). The irregular migrants usually reach Italy using various routes: air and land, air and sea, or all three. A common strategy used is to fly to a transit country on a valid visa and then to enter Italy illegally from there via land or sea. Rahman and Kabir (2012) identify the typical paths that these illegal migrants take: "Bangladeshi migrants often use two land routes from the transit country. In the first route, potential migrants fly to South-Eastern Europe and then travel over land to Italy. In the second route, potential migrants visit Turkey or North-Eastern European countries and use the area of the former Yugoslavia as an entry point to Italy. Some popular transit countries are Poland, Hungary, Albania, Romania, Russia, Turkey, Libya, Tunisia, Morocco and Algeria" (Rahman and Kabir 2012, p. 257). Journey from some of the popular transit countries involve crossing of the Mediterranean Sea, which can be a very precarious crossing and many have lost their lives in the process. Even without such an

8 These countries are Bahrain, Kuwait, Oman, Qatar, Saudi Arabia, and the UAE.

9 For example, they may go as tourists or students and then stay on. 
extreme outcome, the migrants face a myriad of challenges along the way to their Italian destination. Many of these migrants have never left Bangladesh before, do not speak the language spoken in those foreign countries (or even English), and some leave as minors. Many get caught in their attempts to migrate illegally and end up in jail in foreign countries and/or are deported back to Bangladesh where they may have large unresolved debts that they had obtained to finance their journey in the first place (Rahman and Kabir 2012; Quayam 2017b).

Such attempts to get to Italy are extremely perilous. Del Franco (2010, p. 17) found that one of her study participants, a Bangladeshi male in his 20s, "tried 3 times without success to reach Italy. He has always been stopped in Turkey. During the last attempt one of his feet had to be half amputated in a hospital in Istanbul". She describes the experience of another participant and his friends as follows (p. 22): "After working in a factory in the Middle East for one year, [he] attempted to reach Italy together with 3 other Bangladeshi friends. He took 4 months to reach Greece where he was caught without documents and sent to jail. He was repatriated from there through the Bangladeshi Embassy. One of his friends reached Lebanon, another went back to Bangladesh from Turkey after being caught at the border with Greece, and a third one managed to reach and settle in Greece. [His]account of his four-month journey was as enthralling as it was excruciating. He reported that while moving from place to place he was promised good contacts that could help him move forward. Instead he was 'sold' to other dalals (middlemen) who then asked for more money and often kept them starving, hidden in a cellar. In Turkey he was caught and sent to jail. He was convinced he and his friends would all die and admitted that sometimes he wakes up at night thinking about his journey".

IOM Italy (IOM 2017) found that the 619 Bangladeshi migrants who had arrived by sea between 2016 and 2017 and were interviewed by IOM Italy staff had spent on average five months in transit between Bangladesh and Italy and that short journeys of less than a month were uncommon. Almost half of all adults interviewed ${ }^{10}$ had stayed for one year or more in another country after leaving Bangladesh and before arriving in Italy. This made their journey precarious. "Most Bangladeshi nationals interviewed in 2016-2017, both children and adults, reported to have experienced some form of abuse during the journey including working without receiving the expected payment $(75 \%$ of the sample), performing manual and low-skilled jobs (cleaning, housekeeping, gardening, shop assistant, waiter); being forced to work against their will (42 per cent); or being held in a closed place against their will by groups or individuals other than official forces (63 per cent). All children interviewed in 2017 claimed to have experienced at least one form of exploitative practice (unpaid labor, forced labor, arranged marriage, kept against will) in first person. Additionally, 77 per cent and 12 per cent of all migrants reported to have directly experienced physical violence, and to have witnessed sexual violence [respectively]" (IOM 2017, p. 4).

Based on the discussion in this section, it is clear that during the journey from Bangladesh to Italy, many Bangladeshi migrants face precarities in various forms. While life precarity and place/legal precarity appear to be the most common types of precarities faced in this transition period, migrants also face labor precarity.

\subsection{Precarious Life in Italy}

According to a 2016 report by the Italian Ministry of Labour and Social Policies there were 142,403 Bangladeshis regularly residing in Italy on 1 January 2016 (Italian Ministry of Labour and Social Policies 2016) compared to 5541 Bangladeshis officially present in Italy in 1995 (Knights and King 1998). The report noted that in 2016 Bangladeshis constituted 3.6\% of all non-EU citizens in Italy, an increase of $2.6 \%$ from 2015. These figures show the tremendous increase in Bangladeshi presence in Italy in recent times. These figures may only partially include, or not include at all, the so-called irregular Bangladeshi migrants. An estimate of those numbers is not easy to find and may vary widely across

10 A total of 436 adults were interviewed by the IOM. 
sources. For example, the estimated irregular Bangladeshi migrant population in 2009 was reported as being 11,000 and nearly 74,000 by two different sources (Rahman and Kabir 2012). However, available data seems to indicate that there has been a sharp increase in their number to Italy in recent years. According to the IOM (2017), an estimated 8131 Bangladeshi arrived by sea in 2016, and another 7106 did the same between January and May 2017. This made them the second highest nationality by arrival numbers, after Nigerians. These Bangladeshi migrants arrived as irregular migrants to Italy ${ }^{11}$ but the term "irregular" includes various categories of migrants and is also a dynamic concept. As Triandafyllidou and Bartolini (2017, p. 7) state, "Patterns of irregularity are diverse and can include people who crossed a border unlawfully as well as visa over-stayers, children born to undocumented parents, migrants who lost their legal status because of unemployment or non-compliance with certain legal requirements, and last but not least, rejected asylum seekers". Researchers have also used the term "befallen irregularity" (González Enríquez 2014; Vickstrom 2014) and "semi-legality" (Kubal 2013) in the context of these migrants. One reason for doing so comes from the fact that these migrants may move between different status over time, especially in Southern Europe; they may oscillate between having a legal permit to stay and work and lacking that legality, including periods of partial legal status where they may have permit to stay but not to work or vice versa (Triandafyllidou and Bartolini 2017). These conditions, while not just restricted to Bangladeshi migrants in Italy, are examples of place/legal precarity faced by many Bangladeshi migrants in Italy.

It has also been argued in the literature that the host country's laws and regulations contribute to precarity of migrants and in fact may lead to the presence of higher number of irregular migrants within its borders as migrants overstay their visas, work illegally, and of course, enter illegally. Anderson (2010, p. 311) points out that "those workers who are 'illegal' are generally recognized to be highly vulnerable to exploitation and abuse as employers can use their lack of legal status to threaten and control them, and in practice they may be grossly over-dependent on their employers". The role of the host country in adding to migrant precarity is also noted by Triandafyllidou and Bartolini (2017, p. 7) as they write that "by creating conditions of legal stay and work that are impossible to meet, states indirectly support the interests of unscrupulous employers and create ethnic segmentation and hierarchies in the labour market that are functional to the national economy". Another observation is that Italy's periodic changes in immigration laws and regularization since the mid-1980s keep attracting Bangladeshi migrants even if they have to enter illegally, as there is always the hope of obtaining legal status in future given the past experience (Rahman and Kabir 2012; Mannan and Farhana 2014). As the Bangladeshi community in Italy grows, this expansion itself draws more migrants to the country as social networks abroad, close and broad, increase the probability of the intent to migrate internationally and the existence of networks (Manchin and Orazbayev 2018).

According to the 2016 report of the Italian Ministry of Labor and Social Policies, of the regularly residing Bangladeshi migrants in Italy in 2016, 59\% were employed, whereas $11 \%$ were unemployed. ${ }^{12}$ This would mean that the inactivity rate (those not in the labor force) was $30 \%$. However, the report estimates it at $33.7 \%$. Irrespective of the slight discrepancy, this means that a large section of the community is involved in informal sector work and is not part of the official labor force. ${ }^{13}$ Informal sector work is generally considered precarious due to its lack of legality, poor work conditions, lack of access to the usual benefits associated with a formal sector job, and the uncertainty related to its

11 As pointed out before, these migrants are not captured in the BMET statistics on worker outflow to Italy. This is perhaps another indication that they are irregular.

12 For the employed group more than $94 \%$ were male workers. This is partly explained by the fact that over the years Bangladeshi females wishing to migrate for work have faced various governmental restrictions, including outright bans at times (Siddiqui 2008; Sultana and Fatima 2017). Also, given the cultural norm, many Bangladeshi women do not work outside their homes. The Bangladeshi community in Italy is mostly males, with only $28 \%$ women. This is a much higher percentage of males compared to other migrant communities in Italy (IOM 2017).

13 This inactivity rate is also partially explained by female Bangladeshis staying out of work activities outside their homes. 
continuity. This points to precarity related to labor conditions that a large percent of the Bangladeshis may be facing.

IOM reports that "the majority of Bangladeshi migrants are reported to work in the hospitality and retail sectors (62 per cent of the cases), mainly as waiters and cooks, cleaners, porters, salesperson in small shops. Additionally, 22 percent works in the industry sector and an important share is self-employed or run small retail firms" (IOM 2017, p. 2). Of the Bangladeshis in the labor force, $48 \%$ earn between $€ 800$ and $€ 1200$ per month and another $33 \%$ earn less than $€ 800$ monthly, while the remaining 19\% earn more than $€ 1200$ per month (Italian Ministry of Labour and Social Policies 2016). This income range is similar to that for other migrants groups, according to the Report, and can be contrasted with the average annual wage in Italy of approximately $€ 29,000$ per year (or approximately $€ 2417$ per month) (OECD Statistics 2018). While those Bangladeshi migrants who earn less than $€ 800$ monthly will have difficulty maintaining a decent standard of living, especially if they are also remitting money to Bangladesh, even the better-off migrants may be facing labor precarity in terms of their work schedule. We discuss this further in the next section based on the responses from the participants of our field research.

\section{Field Research into Bangladeshis in Italy}

We conducted a small field research of Bangladeshi migrants in Italy in June, 2018, in two adjacent Italian regions: Emilia-Romagna and Tuscany. We interviewed 18 individuals, 16 of whom were owners or workers in small shops or stalls. Of the remaining two, one was a middleman who took small merchandise orders from the shop owners in a market and brought back the goods from the factories within a short time span. Yet another participant was the spouse of a participant, a worker at a stall in a market. She was herself unemployed at the time of the interview. We recruited our participants by identifying some market places in the two regions where we noticed or learnt about an abundance of Bangladeshi merchants. As a team we approached them individually to ask them to complete a questionnaire with 50 survey questions and to take part in a follow-up interview based on 13 semi-structured questions. In some cases, we had the assistance of a person, who knew the area well, to introduce us to the participants. We roughly went "door-to-door" in the two general locations. In total each interaction with them was roughly an hour and all questions were asked in either the respondents' mother tongue, Bangla, or in Italian. None of them opted to converse in English.

About half of our study participants identified lack of jobs in Bangladesh as one of the reasons for migrating from Bangladesh. One of them said that there were jobs there but they did not pay enough. Political unrest and lack of profit in agriculture were also given as reasons for migration by a few of those who we talked to. One said that his father was a potato farmer and they experienced crop loss year after year from flooding and so he decided to migrate to diversify the earnings of the family from agriculture. This comment is in line with what we discussed above related to adverse effects of climate on agriculture and hence on the people who work in the agriculture sector in Bangladesh. Generally their responses indicated they faced labor and life precarities in Bangladesh.

While some of our participants made indirect journeys from Bangladesh to Italy and a couple found some legs of the journey to be risky or dangerous, the majority said that they came directly from Bangladesh and deemed their journey to be non-precarious. According to one who travelled from Turkey to Greece by boat, the sea was very rough and the boat was travelling at a high speed. These conditions made him fear for this life. Our sample is of course quite small, but even there we find some evidence of risky crossings.

Most of the Bangladeshi migrants that we interviewed for this study reported monthly earnings between $€ 800$ and $€ 1200$ per month for the months that they worked. This is consistent with the numbers cited in the previous section on monthly earnings. However, there is seasonality in some of their earnings, depending on how dependent their work is on tourists. While their earnings are quite low on average, our study participants, most of whom were workers in shops or stalls, also reported working very long hours each day; many of them were working $12 \mathrm{~h}$ or more per day, every day of 
the week. Also, most of them reported having only 3-5 days of holiday in the whole year. While it did not appear at all that they were being forced to work long hours, with such a minimal amount of free time during the day or the year as a whole, it is possible that these migrants have no other alternative but to work hard in order to make enough money to remit funds home as well as to support themselves in Italy. They also gave the impression that they would need to work long hours and with few holidays to stay in their current jobs. Given some of their irregular status, or perhaps the possibility of becoming irregular, these migrants may have little option to look for jobs with better labor conditions; they are happy that someone has hired them. As many other researchers (Rahman and Kabir 2012; Del Franco 2010) have pointed out, the ties to families, immediate as well as extended, back in Bangladesh are very strong. Remitting money home is very important for these migrants. An important motive is to earn as much money as possible but not spend too much of it, as the goal is to remit a solid amount regularly. When asked, almost all of the participants indicated that they remitted money to Bangladesh and that their living conditions were very basic, and they often lived with other Bangladeshis and with many roommates in smallish accommodations. Given the non-standard work schedules that most of our participants had, we can conclude that they faced labor precarity as defined by Biglia and Martí (2014) and discussed in Section 2.

Many of the Bangladeshi migrants also face the type of precarity proposed by (Banki 2013). This is the precarity of place, as distinct from labor precarity or life precarity, which is connected to legal status and "describes the condition of not quite homeless, not yet deported or detained" (Banki 2013, p. 454). Not all of the respondents we interviewed were equally vulnerable though. Nevertheless, none were citizens and it is unclear if they all even had the necessary legal documents to have legal status to sojourn in Italy. So they were "denizens", to use Banki's terminology. A good number had been in Italy for quite some time. Some were not able to travel back to Bangladesh as they feared not being let back in at the Italian border. This clearly relates to precarity of place as discussed in Section 2. One individual, who had been in Italy for five years, reported on how he had not been with his wife and daughter since the daughter's birth, while another respondent talked about his inability to visit his family in Bangladesh and how his mother kept crying when they conversed via Skype. This type of situation makes it difficult to make future plans and has potential negative psychological effects on individuals. The former is also an example of life precarity, as discussed in Section 2. Not all of our respondents had the same issues, however. A few said that they were able to return to Bangladesh on an annual basis. Others indicated that their goal was to remain in Italy indefinitely and they merely would want to travel back to Bangladesh to visit family and friends, but for them it was not a priority. If due to money and legal insecurity they could not travel back, in those cases, for some, they accepted that situation as a cost related to the choice they had made. Thus, the precise empirical expression of precarity of place is diverse among our respondents. The extent of precarity of place and the disruptiveness thereof for a given individual depends on his or her exact circumstances.

As Banki identified, one of the ways to offset precarity of place is to rely on social networks. Indeed this group used its own social network heavily, by often living with other Bangladeshis. Most of them also found employment through their social network and their employers were almost always other Bangladeshis. Also, when asking for a favor (e.g., needing someone to cover for them at work if they are ill or need to go somewhere), they rely on others from the Bangladeshi community. This goes to show that social networks are very helpful in dealing with different types of precarity.

The insights from our field study on precarity experienced by Bangladeshi migrants in Italy are generally in line with what we have described in the previous section based on observations obtained from the existing literature, although that literature has not focused on precarity explicitly. However, our field study also highlights that while there are common themes, there are also variations across individuals in terms of precarities experienced. In sum, we can say that as they continue on with their lives in Italy, many Bangladeshi migrants face precarity, in one or more of its forms as discussed. 


\section{Conclusion}

In this article we reviewed the various meanings of precarity that exist in the literature and looked at the experience of the Bangladeshi migrants in Italy using the precarity lens in some of its different forms, i.e., in terms of precarity of labor, precarity of life, and precarity of place (or legal precarity). As has been discussed in the literature, while these are distinct forms of precarity, migrants generally face precarity in many, if not all, of its different forms. While looking at precarity in some of its various guises, we focused on the experience of Bangladeshi migrants in different stages of their journey: (1) before they began their migration and were in their home country of Bangladesh, (2) during their actual journey between Bangladesh and Italy, which in many cases, may not be have been direct and may have involved a long stay at another country or countries, and (3) after arrival in Italy, their current host country.

None of the existing literature on Bangladeshis that we have referred to in this article to provide support for our observations on Bangladeshi migrants explicitly used the lens of precarity to document the experience of the Bangladeshis. Furthermore, while many of the studies that we have used in this article are about Bangladeshi migrants, none of them considered their experiences at the three different stages of migration together, as we have done here.

Based on the observations obtained from the existing literature as well as our field research into 18 Bangladeshi migrants in Italy, we conclude that the use of the precarity lens and the consideration of the experience of the Bangladeshi migrants at various stages of their journey through this lens is useful to highlight how precarious the lives of these migrants have been and continue to be, and the various forms that precarity takes. By detailing the various types of precarity faced by these migrants in different stages of their journey, we show the overlapping and the accumulating precarity faced by them. Our hope is that such knowledge about the Bangladeshi migrants in Italy will help others understand the tremendous difficulties that these migrants encounter and will assist in obtaining more empathy for the dire situations these migrants are often in.

Funding: Financial support from Borders in Globalization, a partnership grant funded by Social Sciences and Humanities Research Council (SSHRC) (Grant no: 895-2012-1022) as well as an SSHRC Insight Grant 435-2015-0943 held by Amy Verdun are gratefully acknowledged. We also thank the Centre for Asia-Pacific Initiatives at the University of Victoria for partially funding our research travel.

Acknowledgments: We thank the guest editor and two anonymous referees for their helpful comments. We are grateful to the Migration Policy Centre at the European University Institute for hosting us while we did our field research. We also wish to thank our study participants for their time and for sharing their stories with us.

Conflicts of Interest: There are no conflicts of interests to report.

\section{References}

Adams, Caroline, ed. 1987. Across Seven Seas and Thirteen Rivers: Life Stories of Pioneer Sylheti Settlers in Britain. London: Tower Hamlets Art Project.

Anderson, Bridget. 2010. Migration, Immigration Controls and the Fashioning of Precarious Workers. Work, Employment and Society 24: 300-17. [CrossRef]

Banki, Susan. 2013. Precarity of place: A complement to the growing precariat literature. Global Discourse 3: 450-63. [CrossRef]

Barbier, Jean-Claude. 2002. A Survey of the Use of the Term Précarite in French Economics and Sociology. Document de Travail, No. 19. Noisy-le-Grand: Centre d'etudes de l'emploi.

Biglia, Barbara, and Jordi B. Martí. 2014. Precarity. In Encyclopedia of Critical Psychology. Edited by Thomas Teo. New York: Springer. [CrossRef]

Bourdieu, Pierre, Alain Darbel, Jean-Paul Rivet, and Claude Seibel. 1963. Travail et Travailleurs en Algérie. Paris and The Hague: Mouton.

Bourdieu, Pierre. 1998. Acts of Resistance: Against the Tyranny of the Market. New York: The New Press. Buchanan, Ian. 2018. A Dictionary of Critical Theory, 2nd ed. Oxford: Oxford University Press.

Butler, Judith. 2004. Precarious Life: The Powers of Mourning and Violence. London and New York: Verso. 
Butler, Judith. 2009a. Frames of War: When Is Life Grievable? London and New York: Verso.

Butler, Judith. 2009b. Performativity, Precarity and Sexual Politics. AIBR. Revista de Antropología Iberoamericana 4: i-xiii. [CrossRef]

Cupolo, Diego. 2017. Explaining the Bangladeshi migrant surge into Italy. IRIN The Inside Story on Emergencies, June 1.

De Peretti, Gaël. 2005. Précaire: Une Catégorie Instable et Fragile. Empan 60: 14-23. [CrossRef]

Del Franco, Nicoletta. 2010. Research Report. International Migration from Bangladesh to Italy: Exploring the Social Impact on Those Left Behind. Working Paper. Brussels: EC, March.

Donato, Katherine M., Amanda R. Carrico, Blake Sisk, and Bhumika Piya. 2016. Different but the same: How legal status affects International Migration from Bangladesh. The Annals of the Academy of Political and Social Sciences 666: 203-18. [CrossRef]

European Parliament. 2017. 'EU Migrant Crisis: Facts and Figures' European Parliament News 30-06-2017. Available online: http://www.europarl.europa.eu/news/en/headlines/society/20170629STO78630/eu-migrantcrisis-facts-and-figures (accessed on 9 April 2019).

Eurostat. 2019. 'People in the EU-Statistics on Demographic Changes'. Available online: https://ec.europa.eu/eurostat/statistics-explained/index.php?title=People_in_the_EU_-_statistics_ on_demographic_changes\#Foreigners_and_foreign-born_populations (accessed on 8 April 2019).

Ghiglione, Davide. 2017. Surge in Bangladeshi Migrants to Italy. Financial Times. video. Available online: https://www.ft.com/video/09106b28-300c-4298-a03c-2005b57a58f5\#description (accessed on 16 April 2019).

González Enríquez, Carmen. 2014. Spain. In European Immigration: A Sourcebook, 2nd ed. Edited by Anna Triandafyllidou and Ruby Gropas. Aldershot: Ashgate, pp. 321-35.

Government of Bangladesh. 2018. Overseas Employment and Remittances from 1976 to 2018. Available online: http://www.old.bmet.gov.bd/BMET/viewStatReport.action?reportnumber=20 (accessed on 16 April 2019).

Henry, Nicholas. 2018. Asylum, Work, and Precarity, Bordering the Asia-Pacific. Basingstoke: Palgrave Macmillan.

Hundle, Anneeth K. 2012. After Wisconsin: Registers of Sikh Precarity in the Alien-nation. Sikh Formations 8: 287-91. [CrossRef]

International Organization for Migration (IOM). 2015. Irregular Migrant, Refugee Arrivals in Europe Top One Million in 2015. IOM 22 December 2015. Available online: https://www.iom.int/news/irregular-migrantrefugee-arrivals-europe-top-one-million-2015-iom (accessed on 9 April 2019).

International Organization for Migration (IOM). 2017. Current Migration Trends from Bangladesh to Italy. Focus on Arrivals by Sea. IOM Briefing. Available online: http://www.italy.iom.int/sites/default/files/documents/ IOM_Italy_Briefing_01_Migration_trends_from_Bangladesh_to_Italy.pdf (accessed on 11 March 2018).

IPCC. 2014. Climate Change 2014: Impacts, Adaptation, and Vulnerability. Part A: Global and Sectoral Aspects. Contribution of Working Group II to the Fifth Assessment Report of the Intergovernmental Panel on Climate Change. Edited by Christopher B. Field, Vicente R. Barros, David J. Dokken, Katharine J. Mach, Michael D. Mastrandrea, T. Eren Bilir, Monalisa Chatterjee, Kristie L. Ebi, Yuka O. Estrada, Robert. C. Genova and et al. Cambridge and New York: Cambridge University Press.

Italian Ministry of Labour and Social Policies (Ministero del Lavoro e delle Politiche Sociali). 2016. The Bangladeshi Community, Annual Report on the Presence of Migrants in Italy, Executive Summary. Rome: Ministry of Labour and Social Policies.

Kartiki, Katha. 2011. Climate change and migration: A case study from rural Bangladesh. Gender and Development 19: 23-38. [CrossRef]

Khan, Alia L. 2012. Creative Adaptation: Bangladesh's Resilience to Flooding in a Changing Climate. In Climate Change Modeling for Local Adaptation in the Hindu Kush-Himalayan Region. Edited by Armando Lamadrid and Ilan Kelman. Bingley: Emerald, pp. 159-75.

Knights, Melanie. 1996. Bangladeshi Immigrants in Italy: From Geopolitics to Micropolitics. Transactions of the Institute of British Geographers 21: 105-23. [CrossRef] [PubMed]

Knights, Melanie, and Russell King. 1998. The Geography of Bangladeshi Migration to Rome. International Journal of Population Geography 4: 299-321. [CrossRef]

Kubal, Agnieszka. 2013. Conceptualizing semi-legality in Migration Research. Law and Society Review 47: 555-87. [CrossRef]

Lavenex, Sandra. 2018. Failing Forward Towards Which Europe? Organized Hypocrisy in the Common European Asylum System. JCMS: Journal of Common Market Studies 56: 1195-212. [CrossRef] 
Mallet, Victor. 2015. Bangladesh: A dangerous rivalry. Financial Times, April 12.

Manchin, Miriam, and Sultan Orazbayev. 2018. Social networks and the intention to migrate. World Development 109: 360-74. [CrossRef]

Mannan, Kazi Abdul, and Khandaker Mursheda Farhana. 2014. Legal Status, Remittances and Socio-Economic Impacts on Rural Household in Bangladesh: An Empirical Study of Bangladeshi Migrants in Italy', MPRA Paper No. 60292. Available online: https://mpra.ub.uni-muenchen.de/60292/ (accessed on 9 August 2018).

Millar, Kathleen. 2017. Toward a Critical Politics of Precarity'. Sociology Compass 11: e12483. [CrossRef]

Morad, Mohammad, and Jure Gombač. 2018. "Probashi” in Italy. New Destinations: Trends, Origins and Profiles of Bangladeshi Migrants in Padova and Cadoneghe. Dve Domovini/Two Homelands 47: 37-52.

Neilson, Brett, and Ned Rossiter. 2005. From Precarity to Precariousness and Back Again: Labour, Life and Unstable Networks. Fibreculture Journal 5. Available online: http://journal.fibreculture.org/issue5/neilsonrossiter.html (accessed on 26 December 2007).

Neilson, Brett, and Ned Rossiter. 2008. Precarity as a Political Concept, or Fordism as Exception. Theory, Culture $\mathcal{E}$ Society 25: 51-72. [CrossRef]

OECD (Organisation for Economic Co-operation and Development) Statistics. 2018. Average Annual Wages. Available online: https://stats.oecd.org/ (accessed on 16 April 2019).

Paret, Marcel, and Shannon Gleeson. 2016. Precarity and Agency Through a Migration lens. Citizenship Studies 20: 277-94. [CrossRef]

Quayam, Nayam. 2017a. Where Are Europe's Illegal Migrants Coming from? Surprise, it's Bangladesh. Washington Post, May. Available online: https://www.washingtonpost.com/news/monkey-cage/wp/2017/05/19/where-areeuropes-illegal-migrants-coming-from-surprise-its-bangladesh/?noredirect=on\&utm_term=.c834a85f6f04 (accessed on 6 August 2018).

Quayam, Nayma. 2017b. Chasing the Dubai Dream in Italy: Bangladeshi Migration to Europe. Migration Policy Institute, October 5. Available online: https://www.migrationpolicy.org/article/chasing-dubai-dream-italybangladeshi-migration-europe (accessed on 6 August 2018).

Rahman, Md Mizanur, and Mohammad Alamgir Kabir. 2012. Bangladeshi Migration to Europe: The Family Perspective. Asia Europe Journal 10: 251-65. [CrossRef]

Riahan, Selim, Bazlul H. Khondker, Guntur Sugiyarto, and Shikha Jha. 2009. Remittances and Household Welfare: A Case Study of Bangladesh. Working Paper Series, No. 189. Philippines: (ADB) Asian Development Bank Economics.

Siddiqui, Tasneem. 2008. Migration and Gender in Asia. The United Nations Expert Group Meeting on International Migration and Development in Asia and the Pacific. Bangkok, Thailand. September 20-21. Available online: http://citeseerx.ist.psu.edu/viewdoc/download?doi=10.1.1.572.2716\&rep=rep1\&type=pdf (accessed on 12 August 2018).

Standing, Guy. 2011. The Precariat: The New Dangerous Class. London: Bloomsbury Academic.

Stojanov, Robert, Ingrid Boas, Ilan Kelman, and Barbora Duží. 2017. Local Expert Experiences and Perceptions of Environmentally Induced Migration from Bangladesh to India. Asia Pacific Viewpoint 58: 347-61. [CrossRef]

Sultana, Humera, and Ambreen Fatima. 2017. Factors Influencing Migration of Female Workers: A Case of Bangladesh. IZA Journal of Development and Migration 7.

The Asian Development Bank and the International Labor Organization. 2016. Employment and the Labour Market in Bangladesh: Overview of Trends and Challenges. ADB Brief No. 62. Manila: The Asian Development Bank and the International Labour Organization.

Tinker, Hugh. 1977. Banyan Tree: Overseas Emigrants from India, Pakistan and Bangladesh. Oxford: Oxford University Press.

Triandafyllidou, Anna, and Laura Bartolini. 2017. Irregular Migrants and Rejected Asylum Seekers: Conceptual and Policy Challenges for Europe. Background paper for COMPAS Autumn Academy 'Strategic approaches to migrants with irregular status in Europe.' Available online: https://www.compas.ox.ac.uk/event/autumnacademy-2017-strategic-approaches-on-irregular-migrants-in-europe/ (accessed on 16 April 2019).

Tsing, Anna Lowenhaupt. 2015. The Mushroom at the End of the World: On the Possibility of Life in Capitalist Ruins. Princeton: Princeton University Press.

United Nations. 2018. Refugees and Migrants. Definitions. Available online: https://refugeesmigrants.un.org/ definitions (accessed on 16 April 2019). 
Vickstrom, Erik. 2014. Pathways into Irregular Status among Senegalese Migrants in Europe. International Migration Review 48: 1062-99. [CrossRef]

World Bank. 2018. The World Bank in Bangladesh. Available online: http://www.worldbankorg/en/country/ bangladesh/overview (accessed on 2 August 2018).

World Development Indicators. 2018. Available online: http://databank.worldbank.org/data/reports.aspx? source= World-Development-Indicators (accessed on 2 August 2018).

(c) (1)

(C) 2019 by the authors. Licensee MDPI, Basel, Switzerland. This article is an open access article distributed under the terms and conditions of the Creative Commons Attribution (CC BY) license (http://creativecommons.org/licenses/by/4.0/). 